УAK (624.131.1:625.7/.8):656.053(-25)

\title{
INFLUENCE OF ENGINEERING-GEOLOGICAL CONDITIONS ON SAFETY WORKING OF A TRANSPORT NETWORK AT THE TRAFFIC INTENSIFICATION
}

\section{ВПАИВ ІНЖЕНЕРНО-ГЕОЛОГІЧНИХ УМОВ НА НААІЙНІСТЬ ЕКСПЛУАТАЦІЇ АОРІГ МІСТА ПРИ ІНТЕНСИФІКАЦІЇ РУХУ ТРАНСПОРТУ}

\author{
Tetiana V. Kril \\ Т.В. Крі^ь
}

Institute of Geological Sciences, NAS of Ukraine, 55-b O. Honchara Str., Kyiv, Ukraine, 01601 (kril@nas.gov.ua)

This study it is set on the example of three presentable areas of streets in Kyiv, that the state of road covering, their operating ability depends on engineering-geological conditions, and can be leveled intensity of the dynamic loads. The features of engineergeological and geodynamic conditions which can result in violations of working of roads are selected. A formation of tearing cracks for areas where lithological composition and physical-mechanical properties of soils is changed as a result of change of the tensely deformed state of the soil bases of roads under act of the dynamic loads are grounded.

Keywords: transport network, engineering-geological conditions, dynamic loads, damage of road covering.

На прикладі репрезентативних ділянок вулиць м. Києва встановлено, що стан дорожнього покриття, його експлуатаційна зАатність залежить віА інженерно-геологічних умов, та може нівелюватись інтенсивністю динамічних навантажень. Виділено особливості інженерно-геологічних та геодинамічних умов, які можуть призводити до порушень експлуатації доріг. Обґрунтовано утворення розривних порушень - тріщин на Аілянках де змінюються літологічний склаА та фізико-механічні властивості ґрунтів в результаті зміни напружено-деформованого стану ґрунтових основ доріг під впливом динамічних навантажень. Ключові слова: транспортний комплекс, інженерно-геологічні умови, Аинамічні навантаження, пошкодження дорожнього полотна.

\section{INTRODUCTION}

The main problem of transport networks in large cities is the state of motor-car roads. Their working ability is reduced due a damage and deformations of road covering, and also from increasing of amount of vehicles and dynamic influences from them.

The influence of dynamic loads from moving vehicles are passed through road covering to soil bases and distributed on distance of 50-80 m away from the road. The arising up in soils physical phenomena lead, depending on lithological composition, to reduction of angle of internal friction on 0,5-16 \% from an initial value, cohesion on 3-14 \%, module of deformation on 0,5-25 \% (Kril, 2015). Such influences can occasion the changes of physical-mechanical properties of soils, activation of dangerous processes in soils bases depending on intensity of traffic, the state of road covering, engineering-geological, geodynamic and meteorological conditions. It leading to damage and deformation of pavement (cracks, pits, potholes), reducing of its resource.

Existing researches deal with determine of reasons of damages and cracks on roads explain theirs occurrence with weather and climatic factors (by the overfall of temperature, excessive precipitations), loads from transport, wear coating materials over time, a failure of technology works. An attempt to explaining cracks on roads with engineer-geolog- ical conditions is done in these researches, particularly with deformation and strength characteristics of soils in bases of road constructions.

The purpose of the investigations is the establishment of influence of dynamic loads from intensive movement of transport on a condition of a road covering in different engineering-geological conditions.

Main tasks: collection and analysis of materials about the engineering-geological conditions of streets and highways of city; determination of specific level of vibration from traffic; establishment of reaction of the different types of soil bases is on the dynamic loads; calculation of the stability of the soil bases of road covering is in PLAXIS.

The solutions of these tasks were carried out for the territory of Kyiv and in more detail for three representative sections of streets.

\section{MATERIALS AND METHODS}

At researches were used materials of the investigating of geological environment of territory Kyiv, the experience of establishment the main descriptions of sources of dynamic loads, building codes for constructing of roads and researches of deformations and cracks on them.

Field observations of damages consisted in fixing, sketching cracks, determination of density nets cracks and its amount. 
The mechanical and mathematical foundations of the theory of engineering geology and engineering-geological similarity were applied in carrying out deformation calculations and evaluation of dynamic loads. Graphic materials are built with using statistical, cartographic methods and with using GIS and technologies of digital design (cartographic package of "MapInfo", module of threedimensional analysis of "Vertical Mapper" and program of analysis of function of 3th variables of "Surfer", package of certainly-element analysis of the program PLAXIS).

\section{DISCUSSION AND RESULTS}

Transport network of city is the complex of different types of transport which contains streets and roads, traffic interchanges. It has a linear-nodular character of placement. The basis of street network of Kyiv is made by radial highways - continuations of the external road-transport approaches from the side of Ovruch, Kovel, Odessa, Kharkiv, Chernihiv, two semicircular highways on the right bank (including the ring road) and areas of meridional highways - on left (Troyeshchyna - Osokorki and Vyshgorod - Hodosivka), and also streets and roads of III- IV categories for traffic regional and local levels.

The general extent of roads and railways exceeds a two thousand kilometers $(2025,75 \mathrm{~km})$. Most of them (42\%) is laid within the limits of Pre-Dnieper upland. $33 \%$ transport highways laid in lowland of Kyiv Polissya, within the limits of the Pre-Dnieper lowland are laid $25 \%$ of ways. Their designing bases on choice of width of traffic way, type of pavement type, amount of stripes, longitudinal slopes, width of sidewalks executed in accordance with the category of road, and taking into account the engineering-geological, and climatic conditions (Works of transport, 2007; Bases and foundations, 2009).

Most of the roads have an asphalt surface in Kyiv, which presently is in the satisfactory state only on the main highways and recently laid or reconstructed roads. Also there are a covering of paving - stone rubble, survived only on some main streets and in the suburbs, in particular on Andrew's Descent, B. Khmelnytsky Str., M. Hrushevsky Str. and others. Also there are considered separately tram tracks with lattice type of rail sleepers.

Transport network such as it is today was formed in the 80 th of the last century. It was designed for traffic levels of those years. In comparing to 80 th the amount of vehicles grew in five times, the levels of dynamic influences increased also.
According to research (Kril, 2015), $52 \%$ territories of the city are subjected to dynamic loads of insignificant level (IV category) - this includes recreational and residential areas; $36 \%$ territories experienced the average middle and middle levels of vibration (III category - $20 \%$, II category - $16 \%$ ); $15 \%$ of Kyiv is influenced by significant levels (category I) exceeding $96 \mathrm{~dB}$ which is near the railroad tracks or at intersections of major highways.

The data bank has been created in Maplnfo for the elements of a transport network of city, which includes the following thematic layers: genetic type of soils, lithological composition, groundwater level, places of probable flooding, declivity of relief, the points of intersection roads with the faults and lineaments of various types (Geoinformation systems, 2015). The additional layers contain the schemes of city roads and the results of field observations of damages and cracks on them.

The analysis and processing data by GIS revealed the following:

The most common soil bases of city roads are alluvial deposits floodplains and terraces, representing almost $50 \%$ of the total length of roads, sand types of those deposits are reliable for exploitation. For conditions Kyiv were found more than 1700 points on streets and highways, where according to maps of Quaternary sediments (Geological map, 1984) genetic and lithological composition are changing.

Streets and highways were selected by the depths of groundwater level and possible flooding, the presence of perched, soils on which maybe subjected to additional moisturing, for example, this is the sections of the Kharkivs'ke Hwy, Brovarsky Ave, Frunze, Bohatyrska, Sim'i Sosninykh Str., Holosiivskyi Ave., Kiltseva Rd et al.

Estimation of the relief was conducted in relation to friendliness to exploitation of roads from the point of view of overflow-pipe and flowing down of surface-water. $37 \%$ of length of streets have declivity the relief of surface $5 \%$, the most heights slopes of roads of city have declivity at over $200 \%$ (preferably a short upper section steep streets).

Steep slopes are distributed in the city, have the increased seismicity compared with base-line. Thus, there were taken into account zones of geodynamic activity and established place of its intersection with highways.

At the evaluation of strength properties of the soil bases, their stability for providing of reliable exploitation of the linear buildings - roads important is taking into account the zones of geodynamic 
activity. Major faults in the city and their intersection nodes are places potential reduction strength properties of soil (near the intersection Bohatyrska Str., Marshal Timoshenko Str., Heroiv Dnipra Str. on Obolon, Trukhaniv island, Osokorki, Degtyari et al.).

The selection of areas of potential reduction of strength properties of soils and geodynamic activity are proposed to do with taking into account their fault density within the unit area.

Damages and cracks on coverage were compared with descriptions of engineering-geological conditions by means of the created database; the relationship is set between homogeneity and heterogeneity soil bases with the orientation of cracks to the axis of roads.

For more detailed researches of exposure dependence of appearance of damages and deformations of coverage from the soils conditions three representative areas were selected (fig. 1). They were select in different geomorphological regions thus, to include the most different types of soils, among widespread on territory Kyiv. Peremohy Ave. is one of the longest highways of city (more than $11 \mathrm{~km}$ ), which stretched out along morena-sandr plain of Kyiv Polissya, going near the river-bed of Lybid; Lesi Ukrainky Blvd., long almost then $2,5 \mathrm{~km}$, is on a loess plateau and ended at Navodnitsky beam, and the third area from two streets of Myropilska and Kurnatovs'koho Str. is located within the limits of floodplain on the left bank of Dnepr. All of them have an asphaltic road surface; there are also rail ways to the tram on the third area. By the intensity of traffic they accordingly belong to 1, 2 and third categories.

Field observations of these areas are conducted for the exposure of longitudinal and transversal cracks. They consist in fixing, sketching cracks, determination of density nets cracks, and its amount. Cracks which are not the result of changes of engineering-geological conditions were separated (it isn't taken into account), namely: cracks, that arose up at braking of vehicles near traffic-lights, crack and deformation around the hatches of water supply and of communication networks, and also damages of asphaltic surface which are the result of fluctuation temperature (Nikolaeva, 2010).

Fig. 2 is a schematic profile of Lesi Ukrainky Blvd. with first soil layers and histograms of physical-mechanical parameters. Because a type and physical-mechanical properties of soils determine stability and operating ability of engineering building, boulevard was preliminary divided into sections in points, where lithological composition and genetic type of the soil bases change. Almost half of road of boulevard are placed on loessial loams (section 5-6) with the module of deformation of 25-27 MPa. Soils such as boulder loams on an section 2-3 are reliable bases.

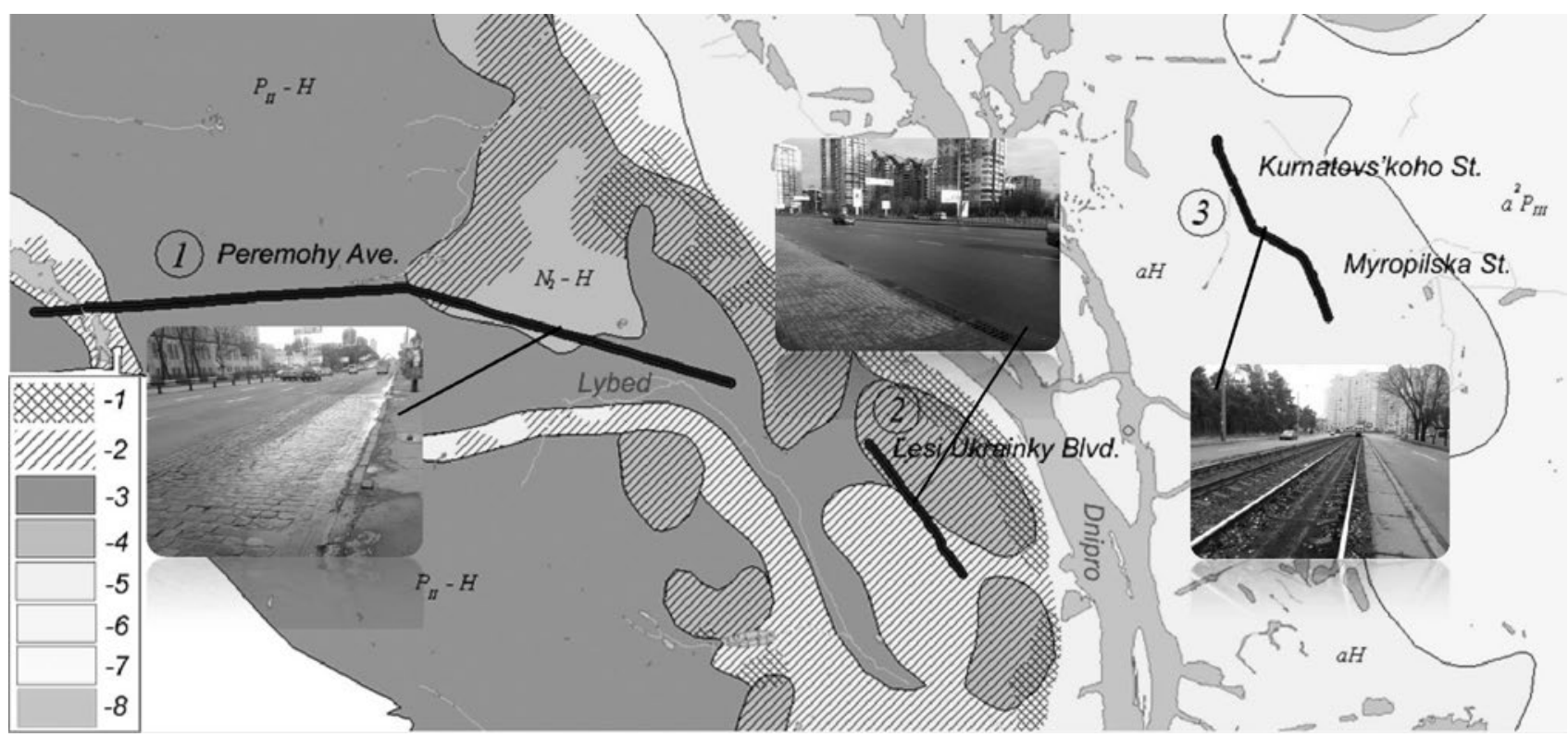

Fig. 1. Position of three presentable roads is in different geomorphologic areas:

1 - the density of the dissection of relief $2-3 \mathrm{~km} / \mathrm{km}^{2}$, depth of relief dissection $20-60 \mathrm{~m}$, the surface inclination of $4-8^{\circ} ; 2-$ the density of the dissection of relief 0-1 km/km2, depth of relief dissection $<20 \mathrm{~m}$, the inclination angles of the surface to $<4^{\circ} ; 3-$ sandr denudation - accumulative form (morena); 4 - loess accumulative - denudation forms; 5-6 - alluvial denudation-accumulative form; 7 - the second terrace; 8 - aquatorium. 
Level of the dynamic load, $d B$

ul. Kutuzova I. Kudri St. M. Pryimachenko Blvd.
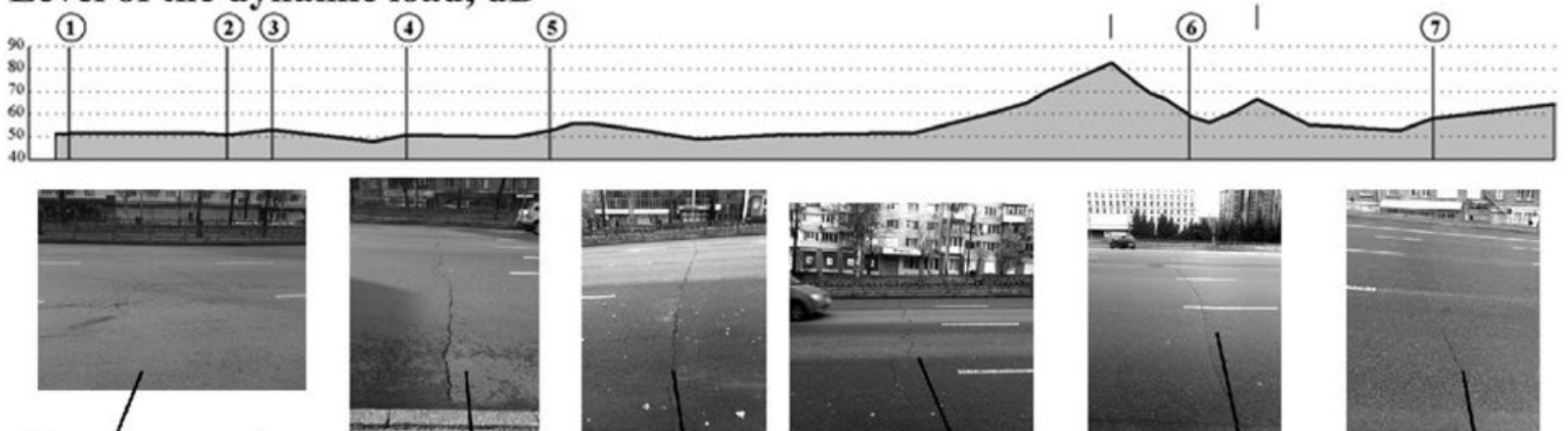

Damages and cracks
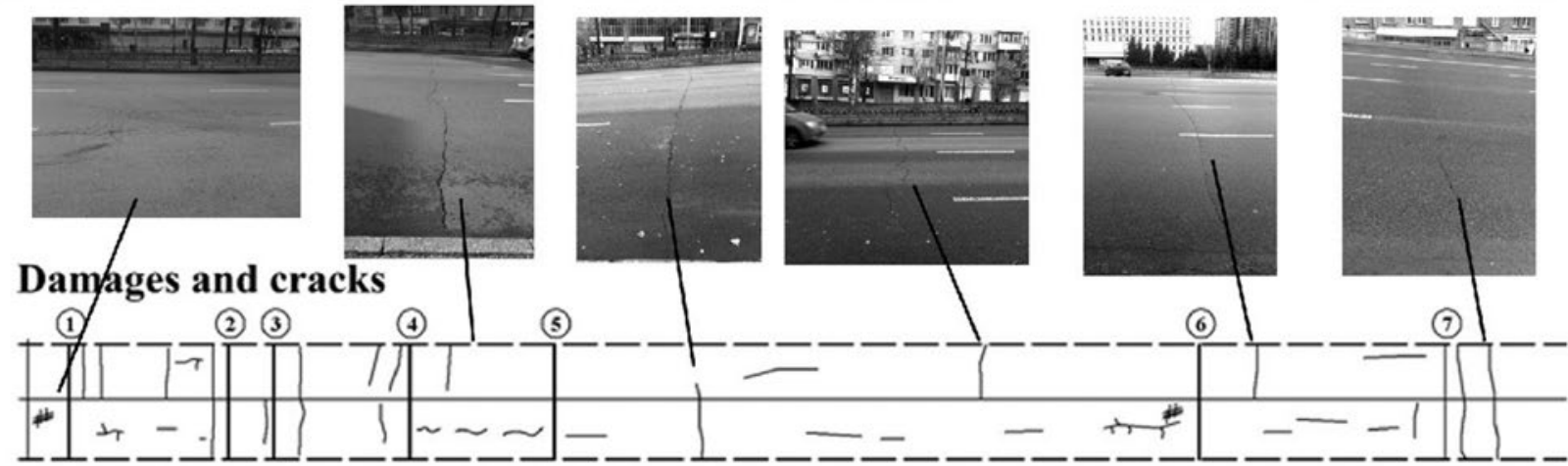

Hypsometric position and first soil layers

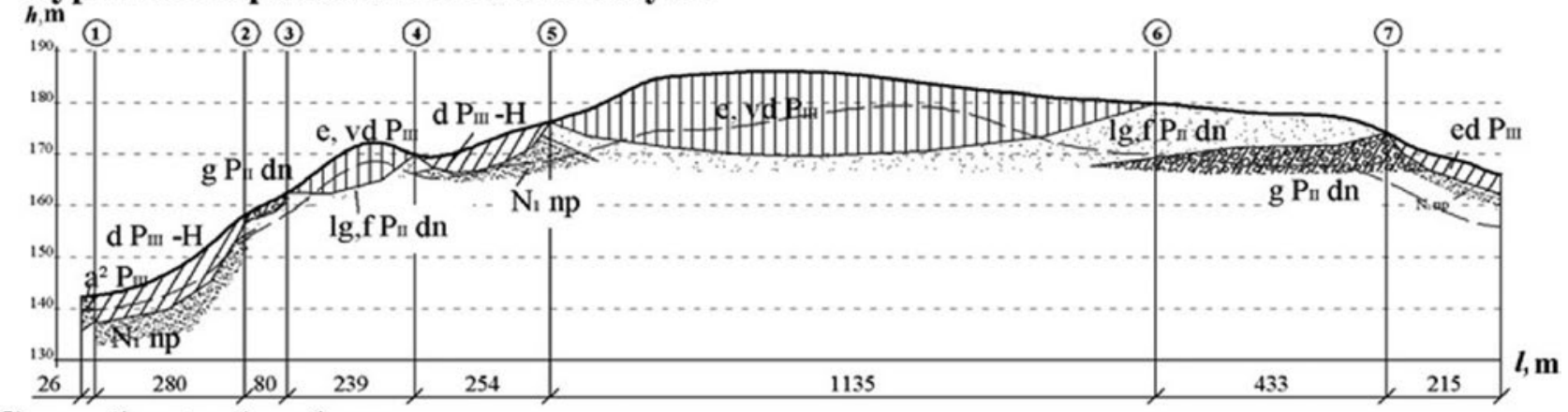

Groundwater level, m

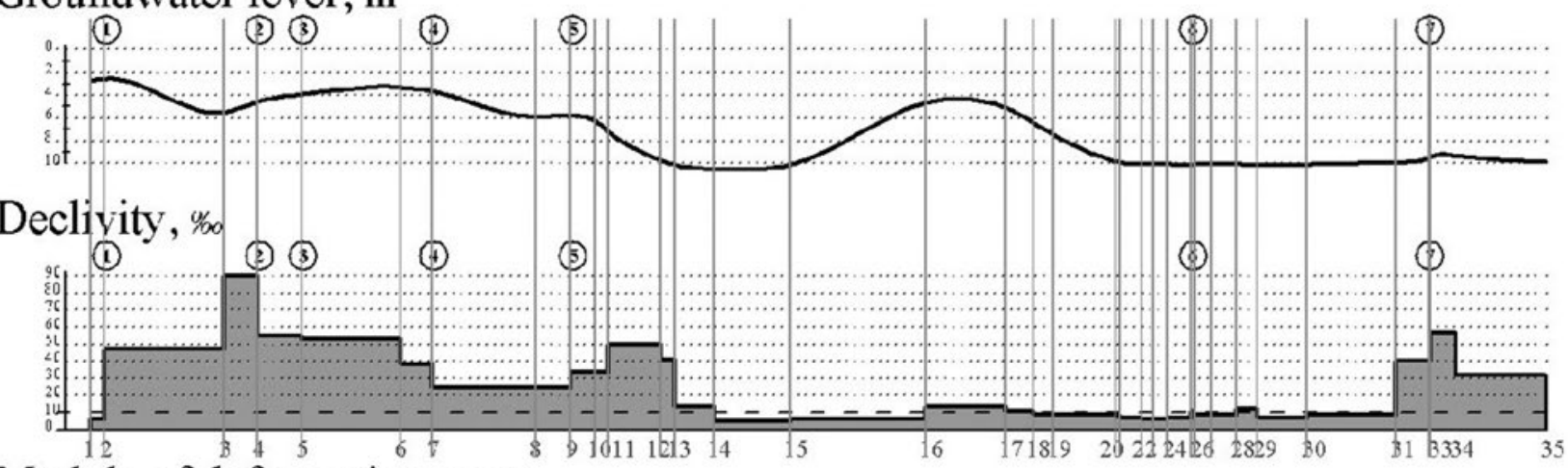

Module of deformation $E, \mathrm{kPa}$

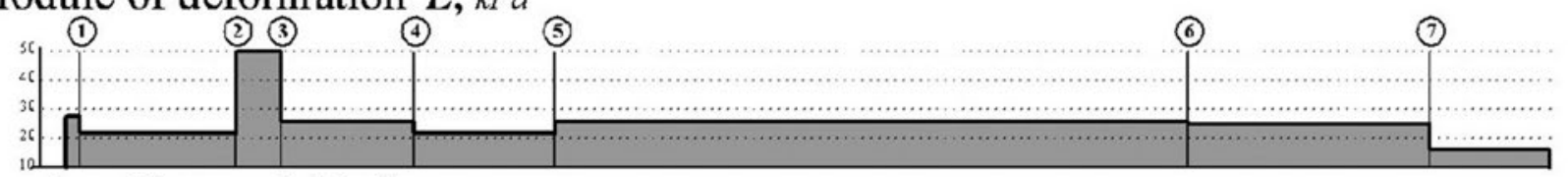

Angle of internal friction $\varphi$, grad

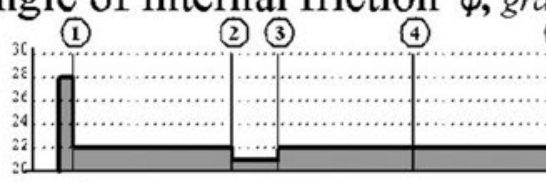

\section{.}

(6)

(7)
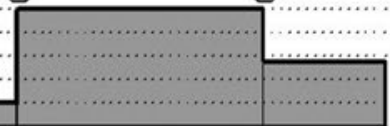

Cohesion $c, M P a$

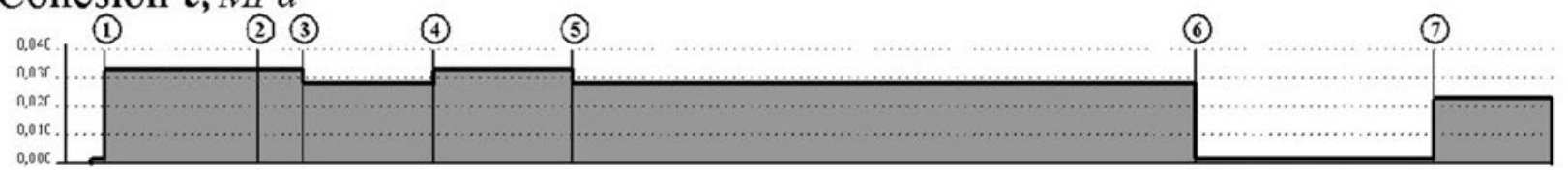

Fig. 2. Characteristics of Lesi Ukrainky Blvd. 
The level of vibrating influence changes from 47 to $60 \mathrm{~dB}$ for vibration velocity (see fig. 2), such levels don't initiate displacement of particles of soil, which leads to further subsidence.

At comparison of fixed damages and cracks with the points of change, it is set that where the soils types is the homogeneous are observed lon- gitudinal cracks that coincide with the axis of boulevard. Transversal cracks tend to the points where lithological composition and genetic type of soils is changes, and accumulated in a radius a $5-15 \mathrm{~m}$ round them.

It is also marked, than steeper declivity, the more encountered small transversal and longitudi-

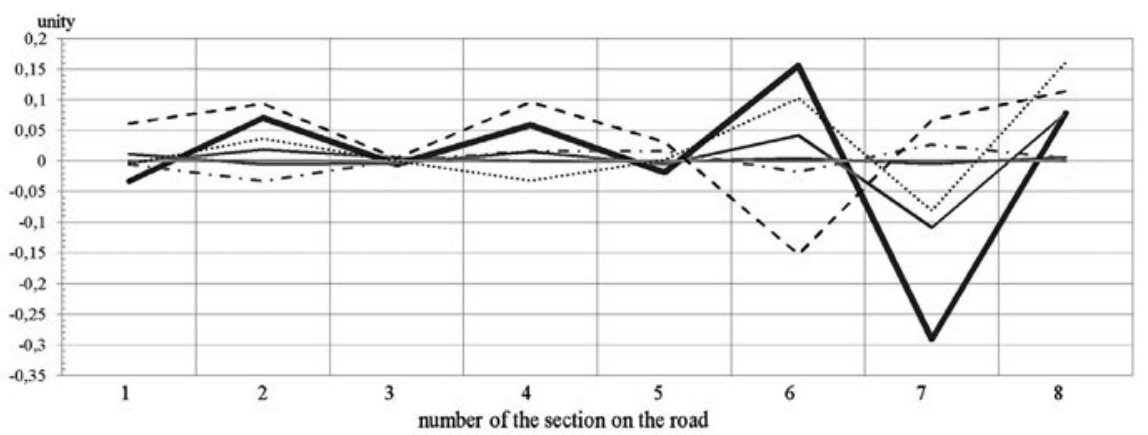

a)
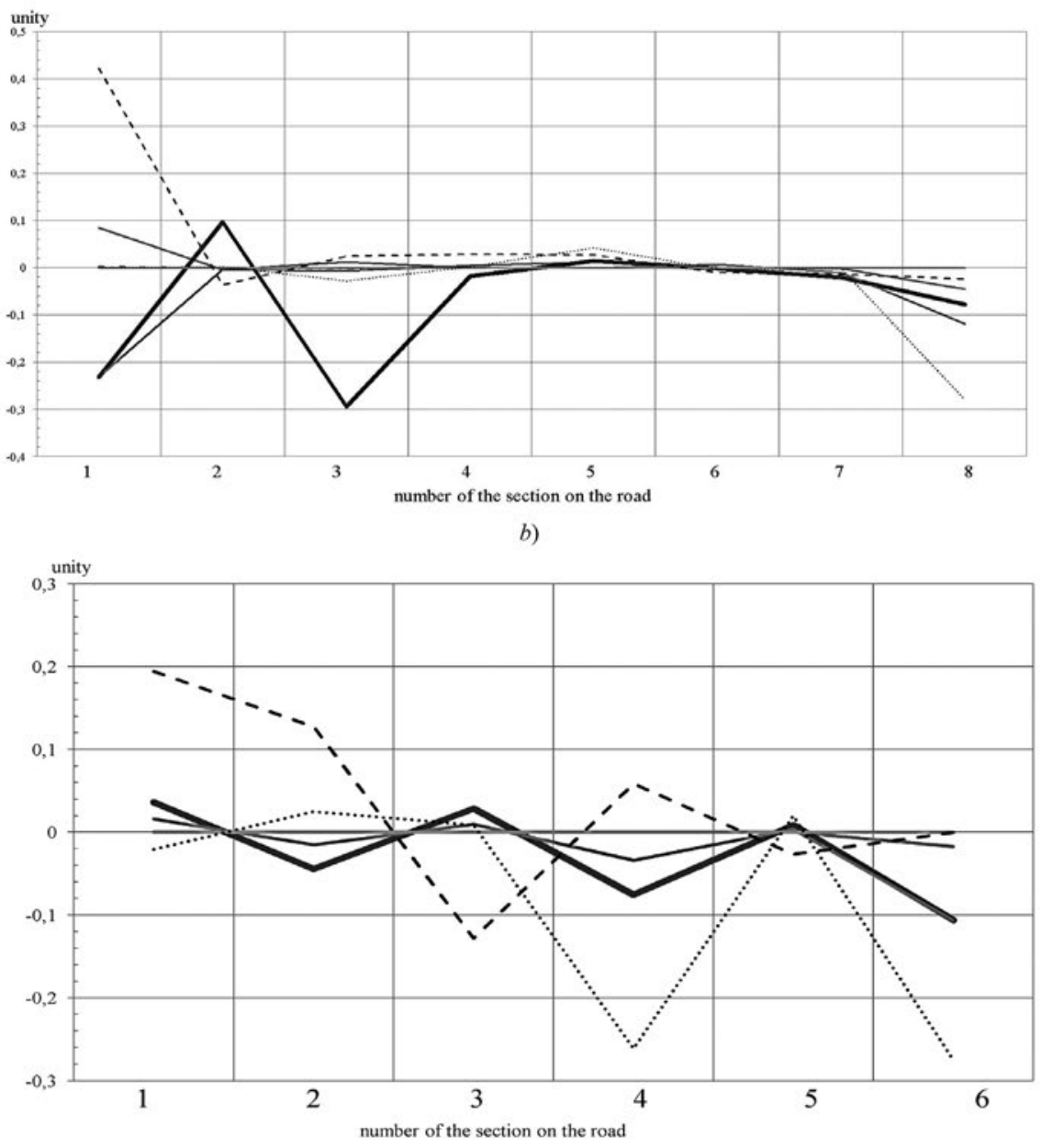

c)

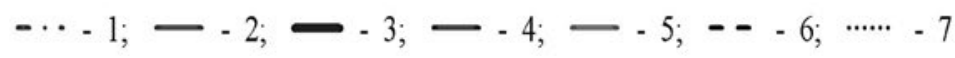

Fig. 3. Comparison of physical-mechanical properties is with the amount of damages in Peremohy Ave. (a), Lesi Ukrainky Blvd. (b), Myropilska and Kurnatovs'koho Str. (c):

1 - declivity; 2 - groundwater level; 3 - modulus of deformation; 4 - angle of internal friction; 5 - cohesion; 6 - amount of damages; 7 - specific level of vibration; 8 - number of the section on the road. 
nal cracks, crossed of their nets, as it was visible on the section 1-3 with slopes to $90 \%$.

Similar researches were done for other two areas.

The analysis of charts of strength parameters, amount of damages and level of vibration from traffic on three presentable areas showed, that there where the module of deformation and cohesion increasing a number of cracks falls, in places where the level of dynamic influence is high - a number of cracks increases (fig. 3).

For research of appearance of cracks as a result of changes in the tensely-deformed state of the soil bases were used the method of certainly- element analysis realized in the program PLAXIS. Calculations were conducted for points, where the overfall of value of the module of deformations of contiguous soils was high.

The calculations of stresses and deformations in soils of roads were carried out by varying the value of the parameter of power dynamic load, namely - amplitude multiplier (Kril, 2015), in each phase of calculation this value was increasing. The chart of increase of plastic deformation from the increase of amplitudes of dynamic influences is shown on fig. 4, $c$.

Fig. 4, $a-b$ represents the results of calculation for a 6 point of Lesi Ukrainky Blvd., where loessial

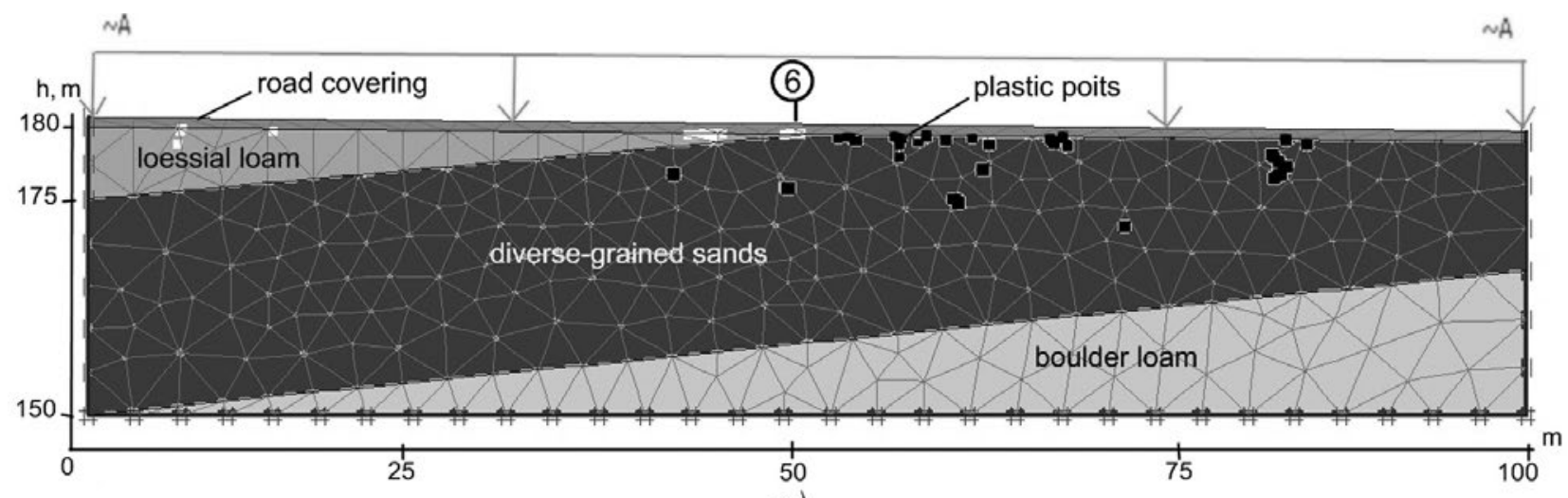

a)

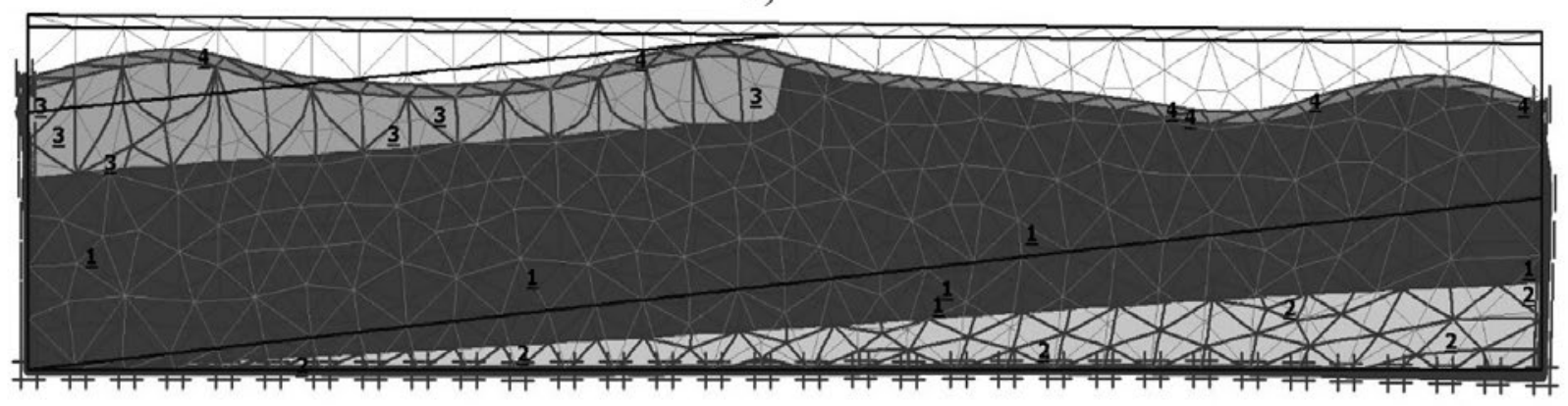

Deformed mesh

Extreme total displacement $121,94 * 10^{-3} \mathrm{~m}$

b)
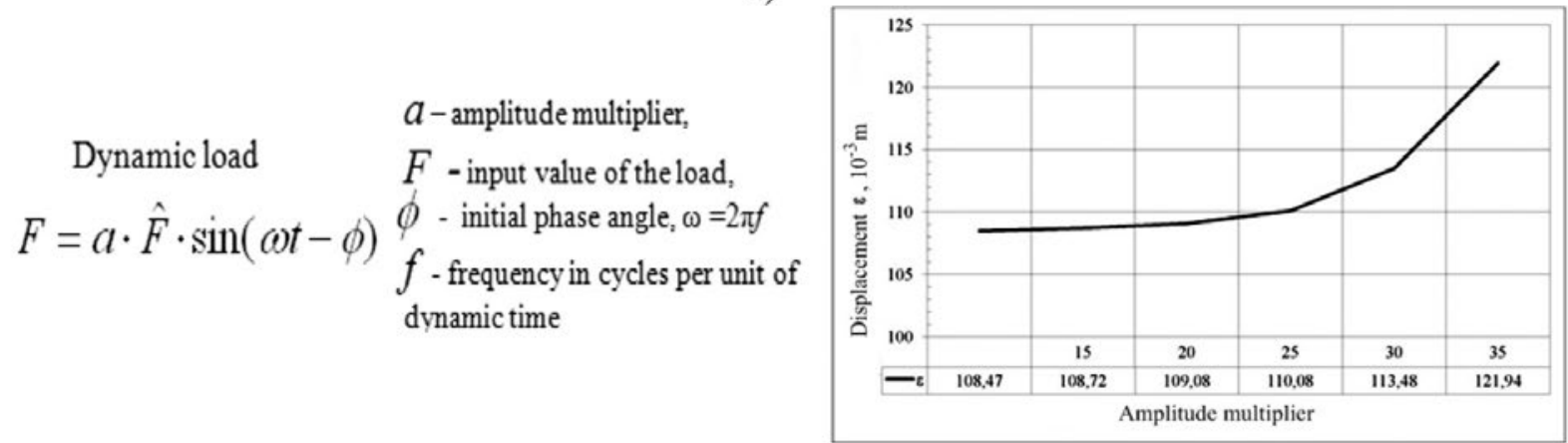

c)

Fig. 4. Calculations of the tensely-deformed state for 6 point in Lesi Ukrainky Blvd.:

$a$ - formation of plastic zones (red squares); $b$ - deformed mesh; $c$ - a chart of increase plastic deformation is from the increasing amplitude dynamic loads. 
loams pass in fluvioglacial sands, the module of deformation on this interval is ranging from 15 to $30 \mathrm{MPa}$. Total displacements of the mesh knots in sands are on $27 \%$ higher, than in loams. Red squares match to the plastical points (zones), which form as a result of compression after the third increase of the amplitude multiplier. If it increase further, numbers of plastic zones will grow.

That is, in soils under the road covering formed plastic zones and with each cycle of increasing of the dynamic load there are their accumulation and increase of deformations. Those deformations are passed to material of coverage where the increase of plastic deformations afterwards results in the origin of such phenomenon as a tiredness of material that in turn results in appearance of tearing deformations and next gradual excrescence of cracks.

The reduced of strength parameter (module of deformation) on $40 \%$ in accordance with a codes (Works of transport, 2007; Bases and foundations, 2009) takes place on $10^{3}$ numbers of cycles (fig. 5). Taking into account, that intensity of motion of traffic may change for a year, week, day, for the duration of cycle it is advisable to take day with attenuation of intensity in a night-time. That is the appearance of damages and cracks is necessary to be expected in the first range which corresponds to about 3-4 years to exploitation of roads.

For the conditions of Lesi Ukrainky Blvd., the current (in 2015) state of its coverage matches appearance of cracks after major repairs in 2011.
For other areas, where duration of the interrepair periods is far higher and there are only partial patching of coverage, such comparisons are impossible through the accumulation of significant numbers of damages on roads.

\section{CONCLUSIONS}

The emergence of damages and deformations of road covering of city in the interrepair periods are due to complication of engineering-geological conditions (the type of soils, groundwater level, declivity of surface etc.), and also vibration influences of different intensity and duration, that occur at moving vehicles. In combination with natural factors, the technogenic have a large value at an increase of intensity of motion and amount of transport vehicles, imperfection of designing and technology of realization of building and repair works.

Damages and cracks on the road covering were compared with characteristics of engineering-geological conditions by means of the created database. Established relationship between homogeneity and heterogeneity of the soil bases with the orientation of cracks to the axis roads; and the conditions of their origin were distinguished.

It is set that where the homogeneous soil conditions are observed the longitudinal cracks that coincide with the axis of road. Transversal cracks are tending to the points where lithological composition and genetic type of soils are changing and forming an accumulation in a radius a 5-15 $\mathrm{m}$ round them. It is also marked, than steeper declivity, the more

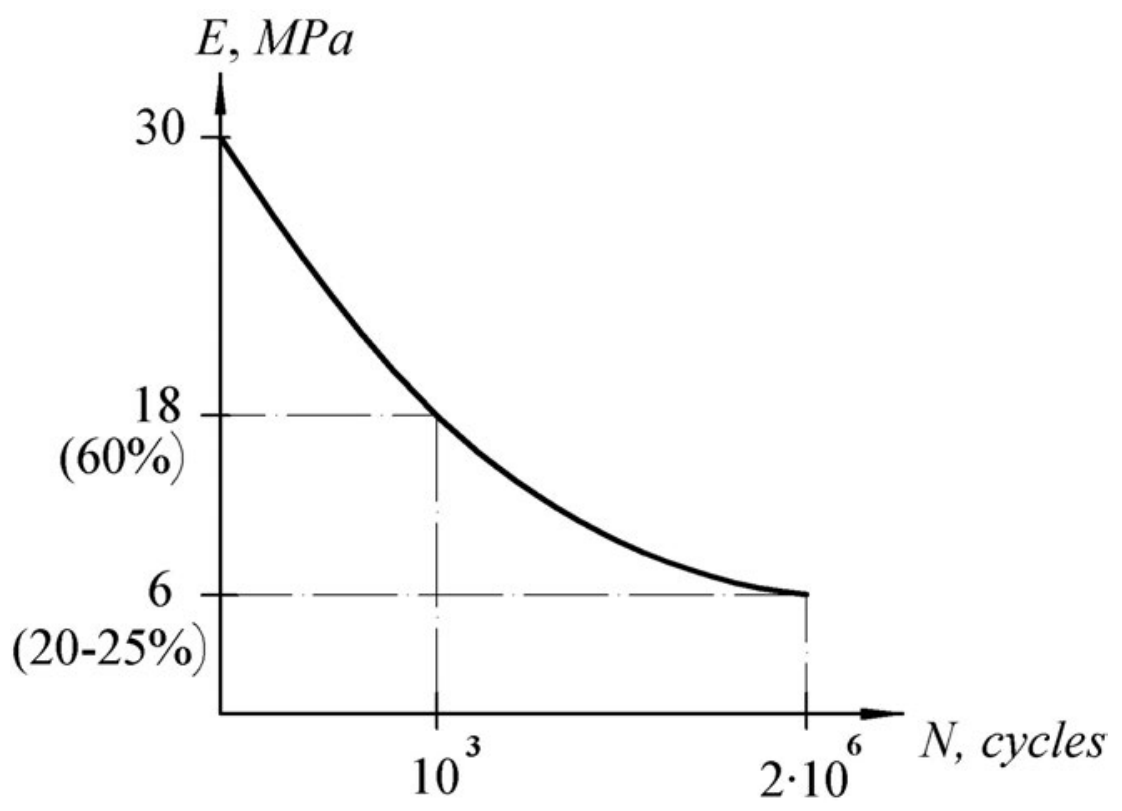

Fig. 5. Reducing of deformation modulus of material is with the increase of amount of cycles. 
encountered small transversal and longitudinal cracks, crossed of their nets, as it was visible on areas with slopes to $90 \%$.

Deformations and different type of damages of road covering should be expected where is a transition between soils of different lithological composition, violation of the groundwater conditions, and also where the high degree of the dynamic loads combines with a "vulnerable" geological environment (significant power loose sediments, watering of technogenic soils etc.).

Calculations of the tensely-deformed state in points, where deformation characteristics of the soil bases are changing gave an opportunity to explain appearance of cracks in road covering as a result of accumulation of plastic deformations and

\section{REFERENCES}

Bases and foundations of buildings, 2009. General design: DBN.2.1-10-2009. Valid from 2009-07-01. Kyiv. Ministry of Regional Development of Ukraine, 104 p. (Gov. system. standards of Ukraine). (In Ukrainian).

Kril T.V., Dubosarskiy V.R., 2015. Geoinformation systems as a tool to identify regional patterns of development of territories. Modern information technology management environmental safety, environmental management, measures in emergency situations: Proceeding of the 14th Int. Sci.-Practic. Conf., Kyiv, pp. 181-189. (In Ukrainian).

Kolot E.I., Cuisina L.P., Kutovoy V.I., Lavrik V.F., Marakhovsky I.I., Selin I., Solovitskiy V.N., Shestopalova E.V., 1984. Geological map of the Ukrainian SSR, scale 1:50 000. Kiev industrial area. In 2 parts V 2. Kiev, 142 p. (In Russian).

Kril T.V., 2015. Technogenic dynamic influences on the geological environment of city (on an example of Kyiv). Kyiv, Naukova Dumka, 160 p. (In Ukrainian).

Nikolaeva E.A., 2010. Fundamentals of mechanics of fracture. Perm, Perm state. tech. University, 103 p. (In Russian).

Works of transport, 2007. Highways: DBN.2.3-4:2007. Valid from 2008-03-01. Kyiv. Ministry of Regional Development of Ukraine, 91 p. (GOS. system. standards of Ukraine). (In Ukrainian). gradual origin of such phenomenon as a tiredness of material that in turn results in appearance of tearing (cracks). First damages and deformations which are the result of influence of engineeringgeological conditions it follows to expect in first 3-4 years of the exploitation of road.

It is suggested to develop the special measures for stability of soils or special constructions of coverage for areas, where lithological composition and physicalmechanical properties of soils bases are changing (for Kyiv more than 1700 such points was set).

The obtained results have an important practical value for development and exploitation of a transport network of city, increase of efficiency repairing works.

Основи та фундаменти споруд. Основні положення проектування : АБН В.2.1-10-2009. - [Чинний віА 2009-07-01]. К.: Мінрегіонбуд України, 2009. - 104 с. - (Аерж. будів. норми України).

Геоінформаційні системи як інструмент Аля виявлення регіональних закономірностей освоєння територій. / Кріль Т.В., Аубосарський В.Р. // “Сучасні інформаційні технології управління екологічною безпекою, природокористуванням, заходами в надзвичайних ситуаціях : матеріали 14-ої міжнарожної наук.-практ. конференції, Київ, ПущаВодиця, 2015. - С. 181-189.

Геологическая карта Украинской СССР масштаба 1:50 000. Киевский промышленный район. Объясн. зап. в 2 ч. Ч. 2. Киев / Э.И. Колот, А.П. Кузишина, В.И. Кутовой, В.Ф. Ааврик, И.И. Мараховская, Ю.И. Селин, В.Н. Соловицкий, Е.В. Шестопалова. - Киев, 1984. - 142 с.

Кріль Т.В. Техногенні динамічні впливи на геологічне сереАовище міста (на прикладі м. Києва). К.: Наукова думка, 2015. - 160 c.

Николаева Е.А. Основы механики разрушения. - Пермь: Из-во Пермского госуА. техн. университета, 2010. - 103 с.

Споруди транспорту. Автомобільні дороги : АБН В.2.34:2007. - [Чинний віА 2008-03-01]. - К.: МінрегіонбуА України, 2007. - 91 с. - (Аерж. будів. норми України). 